\title{
Breast Cancer Detection In Patients Younger Than 40 Years Old In an Opportunistic Screening Population
}

\section{Fırsatçı Tarama Yapılan 40 yaş altı Populasyonda Meme Kanseri Tespiti}

\author{
Oğuz Uğur Aydın ${ }^{1}$, Aydan Ercan² \\ ${ }^{1}$ Ankara Güven Hastanesi Genel Cerrahi Bölümü \\ ${ }^{2}$ Ankara Güven Hastanesi Radyoloji Bölümü
}

Dergiye Ulaşma Tarihi: 05.07.2017 Dergiye Kabul Tarihi: 25.09.2017 Doi: 10.5505/aot.2018.62681

\section{ÖZET}

GIRIŞ ve AMAÇ: Meme kanseri; Türkiye'de kadın kanserleri arasında en sık görülen tiptir. Bu çalışmada nonspesifik şikayetleri olan ve firsatçı tarama yapılan 40 yaş altı kadınlarda meme kanseri oranlarını tespit etmeye çalıştık.

YÖNTEM ve GEREÇLER: Kasım 2011 ile Nisan 2015 arasında Ankara Güven Hastanesi Meme merkezine başvuran 4112 hastaya öncelikli görüntüleme yöntemi olarak meme ultrasonografisi yapıldı. Geriye kalan 3403 $(\% 82,8)$ olgu çalışmaya dahil edilmiştir. Bu kadınların rutin olarak klinik muayeneleri yapılmış; daha sonra USG ile değerlendirilmişler ve gerekli görülen durumlarda başka görüntüleme tekniklerine de başvurulmuştur. Biyopsilerin hepsi meme merkezinde USG eşliğinde yapılmış ve olguların hepsinde kalın iğne biyopsisi tercih edilmiștir.

BULGULAR: Ultrasonografide şüpheli lezyon tespit edilen $292(\% 8,6)$ hastaya ileri inceleme yapılmıştır. Rutin meme muayenesi ve öncelikli görüntüleme yöntemi olarak ultrasonografi tercih edilmiştir. Radyolojik inceleme sonrası 62 hastaya $(\% 1,8)$ kor biyopsi yapılmış ve bunların 14 'ünde $(\% 0,4)$ meme kanseri tespit edilmiştir.

TARTIŞMA ve SONUÇ: Bizim çalışmamızda 40 yaş altında herhangi bir şikâyeti olmayan ya da meme kanseri korkusu olan hastalarda meme kanserinin tespiti için ultrasonografi öncelikli görüntüleme yöntemi olarak kullanılmıştır. Genç popülasyonun ve meme kanseri oranının yüksek olduğu Türkiye'de meme kanserini erken evrede tespit edebilmek için ultrasonografinin öncelikli olarak kullanılması gerektiğini düşünüyoruz.

Anahtar Kelimeler: Meme kanseri, ultrasonografi, 40 yaş altı

\begin{abstract}
INTRODUCTION: Breast cancer is the most common type of cancer in women in Turkey. In this study, we aimed to calculate the breast cancer detection rate in patients who have nonspecific complaints and younger than 40 years old in an opportunistic screening population.

METHODS: A total of 4112 breast ultrasonographies were performed as an initial imaging modality in women between 18 to 39 years old who applied to Ankara Güven Hospital Breast Unit during November 2011 and April 2015. 3403 (82.8\%) cases were included for further examination. Routine breast examinations of these women were done and ultrasonography was performed as the initial imaging procedure. Patients who have lesions that need biopsy had mammography and some of them magnetic resonance 1maging before the biopsy procedure and than core needle biopsy with ultrasonography guidance was performed in all of the cases.

RESULTS: Ultrasonography demonstrated $292(8.6 \%)$ suspicious lesions for further evaluation. After the radiological evaluation was done, core needle biopsy was performed in $62(1.8 \%)$ of these cases and breast cancer was diagnosed in 14 of them $(0.4 \%)$

DISCUSSION AND CONCLUSION: In our study, the ultrasonography was used first for breast cancer diagnosis in women under the age of 40 who did not have any complaint or applied for control due to breast cancer fear. İn Turkey, which has a high young population and therefore faced with breast cancers under the age of 40, the breast ultarsonography has a great role primarily for catching breast cancers in this age group at an early stage.
\end{abstract}

Keywords: Breast cancer, Ultrasonography, under age of 40 


\section{INTRODUCTION}

Breast cancer (BC) is the second most frequently seen neoplasm worldwide and the most common among women $(1,2)$. This statement is also true for women in Turkey (3). Mostly, it affects the women over the age of 50 years old. Despite the fact that the risk of (BC) at the age of 30 's is $0.04 \%$ per year, it is the most frequently seen malignancy at the ages younger than 35 (4).

The possible causes of increased risk of (BC) in younger patients are the late age of first pregnancy, the exogenous and endogenous hormonal effects and changes in nutritional habits (5). Furthermore, existence of a family history is another risk factor for (BC) development at young ages (6).

Breast cancers diagnosed under the age of 40 are more aggressive, progresses rapidly and their prognosis is worse (7). Although, better survival can be achieved in early phase of the disease, curative treatment is not possible in metastatic patients. Since, early diagnosis is vital, screening programs are very important in diagnostic setting. The lack of screening programs before the age of 40 is an important problem for this group. Screening mammography (MG) is the only established screening tool for (BC) (8). Although the start of (MG) screening varies in different countries, it starts generally after the age of 40 .

The incidence of $(\mathrm{BC})$ before the age 40 also varies among countries. The estimated rate of young (BC) patients is higher in Turkey than Europe or USA due to the rate of young population in our country $(9,10)$.

In this group, diagnostic procedures usually start with ultrasonography (USG). In this study, we aimed to calculate the (BC) detection rate in patients younger than 40 years old in an opportunistic screening population.

\section{MATERIAL AND METHOD}

A total of 4112 breast (USG)'s were performed as an initial imaging modality in women between 18 to 39 years old who applied to Ankara Güven Hospital Breast Unit during
November 2011 and April 2015 with nonspesific complaints. All the retrospective data was analyzed and out of these 4112 (USG)'s, 709 (17.2\%) were found to be repeated processes. After they were excluded from the study, the remaining 3403 (82.8\%) cases were included for further examination. Routine breast examinations of these women were done and (USG) was performed as the initial imaging procedure. When necessary, other imaging techniques such as mammography (MG) and/or magnetic resonance imaging (MRI) were performed afterwards. Patients who were referred from another center, applied us for a second opinion, already had an excisional or core needle biopsy and had a (MG) as an initial procedure (because of having high-risk) were excluded.

Patients who have lesions that need biopsy had (MG) and some of them (MRI) before the biopsy procedure and than core needle biopsy with (USG) guidance was performed in all of the cases.

All USG and biopsies were done by the same radiologist.

Breast ultrasounds were obtained on a dedicated breast ultrasound unit (Toshiba Aplio $^{\text {TM }}$ PLT-805 AT8) with a high-resolution linear-array transducer $(6-15 \mathrm{MHz})$

\section{RESULTS}

During 42 months, (USG) demonstrated 292 $(8.6 \%)$ suspicious lesions for further evaluation among 3403 patients and all these patients had (MG) as a second imaging procedure and some of them (MRI) before pathological examination. After the radiological evaluation was done, core needle biopsy was performed in $62(1.8 \%)$ of these cases and breast cancer was diagnosed in 14 of them $(0.4 \%)$.

The age distribution of the patients diagnosed with breast cancer ranged between 29 and 39. There was no serious family history in any of the cases. The smallest tumor size was $5 \mathrm{~mm}$ and the largest tumor size was 30 $\mathrm{mm}$. The pathological findings of the study group were presented in Table 1. 


\begin{tabular}{|c|c|}
\hline & $\begin{array}{c}\text { Opportunistic Screening Population } \\
\text { under the age of } 40\end{array}$ \\
\hline Patients evaluated by the USG & 3403 \\
\hline Patients evaluated by the MG & 292 \\
\hline $\begin{array}{l}\text { Patients went under core needle } \\
\text { biopsy }\end{array}$ & $62(1,8 \%)$ \\
\hline Breast $\mathrm{Ca}$ & $14(0,4 \%)$ \\
\hline Average age & 34 \\
\hline Family history & None \\
\hline Average tumor size & $17,5 \mathrm{~mm}(5-30 \mathrm{~mm})$ \\
\hline Axillary LN+ & $9(64,28 \%)$ \\
\hline Axillary LN- & $5(35,72 \%)$ \\
\hline T1 tumor & $5(35,72 \%)$ \\
\hline T2 tumor & $9(64,28 \%)$ \\
\hline Stage 1a & $2(14,28 \%)$ \\
\hline Stage $2 \mathrm{a}$ & $11(78,57 \%)$ \\
\hline Stage $3 \mathrm{a}$ & $1(7,14 \%)$ \\
\hline
\end{tabular}




\section{DISCUSSION}

During the past 20 years, it is envisaged that the frequency of $(\mathrm{BC})$ is increased 2 folds in Turkey (11-13).

Despite the fact that the risk of developing (BC) increases with age, it is the most frequently seen malignancy under the age 40 in women (14). Based on the American Cancer Society (ACS) data, only $5 \%$ of new women (BC)'s were seen under 40 years old (15). Differing from the western countries, the rate of young (BC) in Turkey and AsianAfrican countries is higher and this rate reached $30 \%$ in some studies (16). In a study conducted by Özmen et al, involving 11208 (BC) patients, it was designated that $20.2 \%$ of these patients were under the age of 40 and moreover, stage 1 and 2 cancer rate was found as $21 \%$ at the eastern Turkey and it was $83 \%$ at the west (17). In our study group, $92 \%$ of the patients diagnosed with breast cancer were at stage 1 and stage 2 . In a study conducted by the same researcher investigating the clinical and histopathological features of 13240 cases with (BC), it was shown that $17 \%$ of the patients were under 40 years old (10). Though it seems like the breast cancer rate under the age of 40 in Turkey is high, considering that the population of the women under the age of 40 makes up $68 \%$ of the total women population, it can be stated that it is at similar rates with the west when correction is made for age distribution for this population. In other words, the reason for this illusion is the high young people population in Turkey.

Breast cancer in young women is usually diagnosed at a more advanced stage because the lack of screening methods, due to dense breast structure and low level of patient awareness (18). Tumors seen in young people have large diameter generally and have higher lymphatic metastasis possibility and higher hormone receptor negativity (19-20). Moreover, high nuclear grade and proliferation rates are some of the features of these tumors (21). It is known that the hormone receptors of breast cancers seen especially under the age of 30 have negative and bad prognosis (22). The diagnosis of breast cancer is delayed in young patients and this in turns causes the occurrence of the disease at advanced stages. The most important reasons of the delay are that young women care less about breast masses and physicians regard these masses less suspicious (23). Again, in Özmen's study, $71.5 \%$ of breast cancers seen in Turkey under the age of 40 were at an early stage (stage 0,1 and 2) and in our study this rate was found as $92 \%$. This rate was exhibited as $77.5 \%$ at the ages over 40 however it was reported that they were younger than the ones in developed countries, they had more advanced-stage breast cancer and worse prognostic factors (10). However, only 1 patient was evaluated at a locally advanced stage (3a) and the remaining patients were diagnosed at the early stages $(1 \mathrm{a}, 2 \mathrm{a})$ in our study.

The (USG) plays an important role for diagnosis of $\mathrm{BC}$ at an early stage in women who are in high-risk group for (BC) and in patients with dense breasts (24-26). It has a sensitivity of more than $95 \%$, and is the preferred initial imaging technique in this patient group. There are studies reporting that its sensitivity is higher than that of the (MG) for malignant lesions in this patient group (16). Therefore, the (USG) must be the first research method to be used for palpable breast masses in young patients however the results must be correlated with the (MG) when needed. There is significant increase in breast screening rates with the USG in the western countries (27). The most significant difficulties concerned with the ultrasonography are that it is an examination based on individuals and it has no uniform malignancy criteria. Hence, setting up breast centers specialized in young age breast cancer diagnosis and employing experienced breast radiologists in these centers would improve early diagnosis rates in this age group.

In our study, the (USG) was used first for breast cancer diagnosis in women under the age of 40 who did not have any complaint or applied for control due to breast cancer fear. The (USG) was performed in 3403 patients and the (MG) was found necessary for 292 of them. The pathologic diagnosis was acquired by performing thick needle biopsy in 62 patients with suspicious lesions when confirmed with the (MG). Though it is seen only scarcely numerically in Turkey, which has a high young population and therefore faced with breast cancers under the age of 40 , the breast (USG) has a great role primarily for catching breast cancers in this age group at an 
early stage.

\section{References}

1. Mintzer D, Glassburn J, Mason BA, Sataloff D. Breast cancer in the very young patient: a multidisciplinary case presentation. Oncologist. 2002; 7(6): 547-554.

2. Kothari AS, Beechey-Newman N, D'Arrigo C, Hanby AM, Ryder K, Hamed is ispiH, et al. Breast carcinoma in women age 25 years or less. Cancer. 2002; 94(3): 606-614.

3. T.C Sağlık Bakanlığı Türkiye Halk Sağlığ Kurumu Türkiye Kanser İstatistikleri http://kanse.gov.tr/Dosya/ca_istatistik/ANA_ra por_2013v01_2.pdf

4. Cardoso F, Loibl S, Pagani O, Graziottin A,Panizza P,Martincich L,et al..The European Society of Breast Cancer Specialists recommendations for the management of young women with the breast cancer. Eur J Cancer. 2012: 48: 3355-3377

5. Fancher TT, Palesty JA, Paszkowiak JJ, Kiran RP, Malkan AD, Dudrick SJ. Can breast selfexamination continue to be touted justifiably as an optional practice. In J Surg Oncol 2011: 96; 54-64

6. Young SR, Pilarski RT, Donenberg T, Shapiro C, Hammond LS, Miller J, et al. The prevalence of BRCA1 mutations among young women with triple-negative breast cancer. BMC Cancer. 2009; 9: 86.

7. Gefewel H, Salhia B. Breast cancer in adolescent and young adult women. Clin Breast Cancer. 2014; 14(6): 390-395

8. World Health Organisation (WHO) WHO position paper on mammography screening. Switzerland: WHO; 2014.

9. Stewart BW, Wild C. International Agency for Research on Cancer; World Health Organization. World Cancer Report 2014. Geneva: World Health Organization; 2014.

10. Özmen V. Breast cancer in Turkey: Clinical and histopathological Characteristics (Analysis of 13240 patients) J.Breast Health 2014;10: 98105

11. Kartal M, Ozçakar N, Hatipoglu S, Tan MN, Guldal AD. (2014). Breast cancer risk perceptions of Turkish women attending primary care: a cross-sectional study. BMC Womens Health, 14: 152.

12. Tuncer M. (2009). Ulusal kanser program1 2009-2015. [National cancer program 20092015]. Ankara: Cancer Fighting Department of Health Ministry of Turkey

13. Köse MR, Bora Başara B, Güler C, Yentür GK. (2015). [Health Statistics Yearbook 2014].

14. Cancer Incidence in Sweden 2008. National
Conflict of interest: None

Board of Health and Welfare. 2009.

15. American Cancer Society. Breast Cancer Facts \& Figures 2013-2014. Atlanta: American Cancer Society, Inc. 2013.

16. Agarwal G, Pradeep PV, Aggarwal Y, Yip CH, Cheung PS. Spectrum of breast cancer in Asian women. World J Surg 2007; 31: 1031-1040.

17. Özmen V. Breast cancer in the world and Turkey. J Breast Health 2008: 7-12.

18. Goksu SS, Tastekin D, Arslan D, Gunduz S, Murat A, Tatlı DU, et al. Clinicopathologic features and molecular subtypes of breast cancer in young women (age $\leq 35$ ). Asian Pac J Cancer Prev 2014; 15: 6665-6668.

19. Anders CK, Johnson R, Litton J, Phillips M, Bleyer A. Breast cancer before age 40 years. Semin Oncol 2009; 36: 237-249.

20. Fredholm H, Eaker S, Frisell J, Holmberg L, Frederiksson I, Lindman H. Breast cancer in young women: poor survival despite intensive treatment. PLoS One 2009; 4: e7695.

21. Eugenıo DS, Souza JA, Chojnıak R, Bitencourt AG, Graziano L, Souza EF. Breast Cancer features in women under the age of 40 . Rev Assoc Med Bras 2016; 62: 755-761

22. Yongqiang Yao, Mingqian Cao, Hong Fang, JiPing Xie. Breast cancer in 30 year old or younger patients: clinicopathologic characteristics and prognosis. World J. Surg Oncol. 2015 Feb. 12;13:38.

23. Jassem J, Ozmen V, Bacanu F, Drobniene M, Eglitis J, Laksmaiah KC, et al. Delays in diagnosis and treatment of breast cancer: a multinational analysis. Eur J Public health 2014; 24:761-767

24. Cilotti A, Bagnolesi P, Moretti M, Gibilisco G, Bulleri A,Macaluso AM, et al. Comparison of the diagnostic performance of high-frequency ultrasound as a first- or second-line diagnostic tool in non-palpable lesions of the breast. Eur Radiol 1997; 7: 1240-1244.

25. Corsetti V, Ferrari A, Ghirardi M, Bergonzini $\mathrm{R}$, Bellarosa $\mathrm{S}$, Angelini $\mathrm{O}$, et al. Role of ultrasonography in detecting mammographically occult breast carcinoma in women with dense breasts. Radiol Med 2006; 111: 440-448.

26. Vercauteren LD, Kessels AG, van der Weijden T, Koster D, Severens JL, van Engelshoven $\mathrm{JM}$, et al. Clinical impact of the use of additional ultrasonography in diagnostic breast imaging. Eur Radiol 2008; 18: 2076-2084.

27. Parris T, Wakefield D, Frimmer H. Real world performance of screening breast ultrasound following enactment of Connecticut Bill 458 . Breast J 2013; 19: 64-70. 